\title{
8 Semi-Opponents in Power: The Abdurrahman Wahid and Megawati Soekarnoputri Presidencies
}

\author{
EDWARD ASPINALL
}

Indonesia's transition between authoritarian and democratic forms of government was marked by a curious combination of circumstances: the most far-reaching reforms were carried out by a leader from the old authoritarian regime; once critics of that regime came to power, reforms slowed down.

As Dewi Fortuna Anwar explains in the preceding chapter, most of the major structural reforms that occurred during Indonesia's transition took place during the brief presidency of Habibie. Habibie, of course, had been a prominent member of the New Order elite. After he fell, Indonesia was ruled in quick succession by two individuals, Abdurrahman Wahid and Megawati Soekarnoputri, who had been (with qualifications explained below) prominent leaders of opposition, or at least of oppositional sentiment, during the preceding New Order regime.

Yet Abdurrahman's and Megawati's governments achieved relatively little in terms of substantive reform. The release of political prisoners, the lifting of restrictions on political parties, trade unions and other political organisations, reform of the electoral system, the removal of the military from formal politics, and political decentralisation: all of these were achievements, or at least initiatives, of the Habibie period. During the succeeding two presidencies, there were some adjustments to Habibie's reform blueprint, but in some areas reform also stalled.

There are many different ways to explain the vicissitudes of the Indonesian transition and the relatively limited progress of political reform after Habibie. The fast accumulating journalistic and scholarly literature points to a number of culprits. Most analysts stress contextual factors and sources of authoritarian resistance. In the Indonesian public debate at the time, many commentators pointed to resistance by 'status quo' forces. Some scholarly works echo this approach, emphasising the obstacle to reform represented by a recalcitrant military and bureaucracy (e.g. Barton 2002:382-84). Hadiz and Robison (2004), 
in a more sophisticated version of this argument, stress the resilience and reconsolidation of oligarchy. Others blame the severity of the economic crisis that Indonesia faced, as well as the degree of violence and ethnic, separatist and other forms of conflict that Indonesia was experiencing (e.g. ICG 2000). Yet another strand of analysis stresses the tenacity of the culture of corruption and patrimonialism (e.g. McLeod 2005; Mackie in this volume).

One common view is that the really sharp break, and a decisive defeat for reformasi, came with the collapse of Abdurrahman Wahid's presidency in July 2001. In this view, Abdurrahman came to power as the counter-reformasi forces were reconsolidating. Aroused by his reformist views, they rallied their forces, sabotaged his government and eventually defeated him. Megawati's government, by contrast, made peace with the forces of reaction and even came to embody the counter-reformasi impulse (see Barton 2001; Kingsbury 2002:297; Vickers 2005:212).

This chapter presents a different interpretation. It stresses the similarities and continuities between the Abdurrahman and Megawati presidencies rather than the differences. It emphasises how reform was undermined from within government during these presidencies, including from the very top, as a consequence of leaders' coalition-building choices and styles of political behaviour. These choices and styles, it is further argued, may in turn be related to a legacy of the New Order period that is not often emphasised: the lasting effect of the methods the regime used to deal with potential opponents. Building on an argument about the nature of political opposition under the New Order developed elsewhere (Aspinall 2005), it is here suggested that the New Order encouraged a distinctive 'semi-oppositional' style in civil and political society, that both Abdurrahman and Megawati were products and exemplars of this style, and that many of the vicissitudes of their presidencies can be explained by this dynamic.

\section{The New Order and its legacy}

A kind of revisionism has taken hold of scholars since the New Order regime fell. During the New Order years, some observers arguably took some of the regime's legitimating claims too seriously (see van Klinken 2001 for one critique). Since the regime fell, by contrast, there has been a reverse tendency. Now scholars emphasise the violence of the regime (e.g. Anderson 2001), its criminal nature (Lindsey 2001), and its use of repression, to the exclusion of all else. At least in one section of the Indonesian studies field there is a new orthodoxy that violence and exclusion were the essence of the New Order. 
It is undeniable that repression was fundamental to the New Order. However, it was only one half of the means by which the regime managed potential opposition. For the majority of political actors the regime was, at least by its final decade, not especially violent. Setting aside the large numbers the security forces killed in anti-separatist operations in East Timor, Aceh and Irian Jaya, where nationalist ideology and guerilla organisation gave a special force to opposition which was absent elsewhere, the number of people directly killed in political violence by agents of the state in the final years of Soeharto's rule between 1990 and 1998 was relatively low. Of course, as Heryanto (2006) has argued, the memory and threat of violence was inculcated into the fabric of citizens' daily lives and could thus be debilitatingly effective without always being overt. Even so, the exclusive focus on violence and repression misses much about the New Order, and thus fails to capture important aspects of its legacy.

As I have argued elsewhere (Aspinall 2005), one key to the New Order's longevity and success was the way it combined violence (and the threat of violence) with co-optation and toleration. The regime did not merely prohibit threatening forms of political action and ideology, it also allowed a relatively wide variety of organisation and representation of societal interests - political parties, the societal organisations or ormas, NGOs and the like - so long as they did not fundamentally challenge the regime and adapted to its rules.

This situation inculcated a distinctive form of political behaviour even in most political actors who sought to remain independent from or even challenge the regime. Following Linz, this form of political behaviour is known as semi-opposition. Semi-opponents were, in Linz's words, 'those groups that are not dominant or represented in the governing group but that are willing to participate in power without fundamentally challenging the regime.' (Linz 1973:191; also Aspinall 2005:6-7, 145-76). Semi-opponents worked within regime-sanctioned bodies like parties and ormas. They learned how to express criticisms in ambiguous language, how to work within regime structures while endeavouring to maintain some degree of autonomy, and how to carefully read the signs emanating from the regime's leaders in order not overstep the everchanging line separating tolerated political behaviour from that which was suppressed. The combination of repression with toleration created a dominant political culture of compliance, compromise and moderation.

This culture was especially strong among the representatives of the old aliran, the major socio-cultural streams which had dominated Indonesia's political life before the rise of the army in the late 1950s and mid-1960s. The most obvious were the modernist Muslims of Muhammadiyah, with about 20-25 million followers by the late New Order and the traditionalist Muslims of Nahdlatul Ulama (NU), around 30-35 million. The Sukarnoist nationalists - many of whom 
were drawn from the Javanese nominally Muslim cultural variant or 'abangan', or who were members of minority religious communities - were more loosely organised but equivalently numerous. They were represented primarily through the regime-tolerated political party, the Indonesian Democracy Party (Partai Demokrasi Indonesia, PDI).

Significantly, the leaders of each of these three currents, respectively Amien Rais, Abdurrahman Wahid and Megawati Soekarnoputri, became the major political figures of the immediate post-Soeharto years. Their prominence was not fortuitous. Semi-oppositional forces were in advantageous positions when the New Order collapsed. They had managed to preserve a political apparatus throughout the New Order years, albeit mostly by compromising with the regime. Partly as a result, they had also been able to retain mass constituencies. More radical opponents of the regime, by contrast, had been isolated, repressed and prevented from gaining access to the public. Moreover, because semiopponents were not from the inner core of the regime or implicated directly in its failings, they were now able to present themselves as a political alternative to it. This was especially the case because during the New Order's final decade, as political tensions had increased, some of the chief semi-oppositional leaders and their organisations had become more independent and had more openly criticised the regime.

The obvious exemplar of this trend was Megawati Soekarnoputri, daughter of Indonesia's first president, Sukarno, an embodiment to many Indonesians of Sukarno's populist spirit. In a sign of erosion of the regime's political control mechanisms she had attained the leadership of the PDI because of her grassroots support in 1993. She was subsequently removed from her post on Soeharto's orders in 1996, conferring on her much public admiration as a victim of the New Order. Amien Rais, who became chairperson of Muhammadiyah in 1995, was also becoming by 1996-97 a leading public critic of Soeharto. Abdurrahman Wahid, the head of NU, had also been critical of the government during its last decade and narrowly avoided being unseated in a government-organised plot to remove him as NU leader in 1994. From 1996-97, however, Abdurrahman assiduously courted Soeharto and his circle in order to ensure that NU and his own leadership were no longer undermined.

In the first post-Soeharto election in 1999, 64 per cent of the vote was won by parties which either had themselves formerly been in a semi-oppositional relationship with the New Order, or were linked to mass organisations which had been in such a relationship. These parties were the new incarnation of Sukarnoist nationalism, Megawati's Indonesia Democracy Party-Struggle (Partai Demokrasi Indonesia-Perjuangan, PDI-P) winning 34 per cent of the vote; the party of Abdurrahman Wahid's wing of the largest Muslim organisation in Indonesia, NU; the National Awakening Party (Partai Kebangkitan Bangsa, 
PKB), 13 per cent; the party of modernist Muslims led by Amien Rais, the National Mandate Party (Partai Amanat Nasional, PAN) 7 per cent, as well as the United Development Party (Partai Persatuan Pembangunan, PPP), 11 per cent, an Islamic party that had been created by and tolerated by the New Order. More radical forces espousing 'reformasi total' were entirely unable to organise and become a credible electoral force.

Politics in the post-Habibie period were thus dominated neither by former New Order stalwarts nor by former unbending opponents of the regime, but instead by its former semi-opponents. They brought with them the habits and political outlook that had been inculcated in them during the New Order years. The remainder of this chapter looks at the effects by focusing on Indonesia's second and third transitional governments, those of Abdurrahman Wahid and Megawati Soekarnoputri.

\title{
The Abdurrahman Wahid presidency (October 1999-July 2001)
}

\begin{abstract}
Abdurrahman Wahid has long been an intriguing figure in Indonesian politics. Unusually liberal-minded for such a senior member of Indonesia's political elite, let alone for an ulama from a blue-blooded Nahdlatul Ulama dynasty, he had also confounded many Indonesian democrats in the final years of Soeharto's reign by realigning with the president's camp and opening his NU constituency up to Golkar and the President's daughter Siti Hardiyanti Rukmana or 'Tutut' (on this see Aspinall 2005:197-98). Yet when he came to power he surprised observers with the radicalism of some of his political rhetoric and associations. For instance, he called for the unbanning of Marxism-Leninism and apologised to victims of the anti-Communist 1965-66 massacres. He publicly associated with individuals like the left-wing author Pramoedya Ananta Toer who had long been persona non grata in elite culture and politics.
\end{abstract}

His actions were also more than merely symbolic. He initiated efforts to overhaul government policy and structures in key areas which, had they been successful, would have transformed Indonesian politics even more fundamentally than had Habibie's reforms. There is insufficient space to explore his agenda in detail, but we can mention two illustrations. First, Abdurrahman initiated plans to begin a major restructuring of the military's territorial command structure, the very foundation of the military's institutional autonomy and pervasive political influence. In order to achieve this goal he cultivated and attempted to promote an outspoken military officer, Agus Wirahadikusumah, who antagonised conservative members of the officer corps with his bold plans for military reform (Mietzner 2006). 
Second, Abdurrahman brought a bold approach to the handling of regional, especially separatist, unrest. In Aceh, after first promising a referendum on independence (he immediately and confusingly backtracked), he initiated negotiations with exiled Free Aceh Movement (Gerakan Aceh Merdeka, GAM) rebels, a step previously rejected by the Habibie administration. Abdurrahman took a leading personal role in initiating negotiations (indeed, he even personally telephoned a leader of a minority GAM faction in Sweden and offered him Aceh's governorship in exchange for a peace deal: interview with Husaini Hasan 13 June 2004). His approach bore fruit in the form of a preliminary peace deal, the 'humanitarian pause' of mid-2000. On Papua, he was no less bold, making a famous visit to the province on new year's day 2000 when, at dawn, he renamed the province Papua (previously, it had been called Irian Jaya, a term resented by many locals). He even funded the Papuan People's Congress later that year, an event which became an important forum for expression of Papuan grievances and nationalism (Chauvel 2003:27-32). His approach to these conflicts was marked by naiveté and inconsistency, but it also marked a dramatic break with past practice and antagonised many in the security establishment.

Yet almost nothing came of these ambitions. The debacle of the Abdurrahman Wahid presidency has been discussed thoroughly elsewhere (Liddle 2001; Aspinall 2002; Malley 2002; Mietzner 2001, 2004). Having constructed a fragile coalition to win office, Abdurrahman set about dismantling it almost immediately he came to power. By sacking ministers from the parties who had supported him and publicly taunting their leaders, he invited confrontation with the legislature and political parties. By its end, his presidency had degenerated into farce. Most of the parties which had earlier backed his presidential bid turned against him. Abdurrahman responded by making increasingly erratic and inflammatory comments about friends and foes alike and threatening, but proving unable, to dissolve parliament and rule by decree. Eventually, he was forced from office by impeachment on 23 July 2001.

Abdurrahman's presidency left very little lasting legacy of reform. One could argue that the Helsinki Agreement of August 2005, which may become the foundation of a lasting peace in Aceh, was the culmination of his efforts to begin negotiations to the conflict there. The special autonomy laws for Aceh and Papua that were signed into law by Megawati shortly after Abdurrahman fell, were also largely negotiated during his presidency, although the prime movers here were forces in parliament rather than in the executive. In both cases, it is likely these outcomes would have happened regardless of Abdurrahman's presidency. Certainly, by its end, Abdurrahman's reform plans were in disarray. Security forces were returning to repression in both Aceh and Papua. Plans to restructure the military had stalled. 
The point here is not simply that Abdurrahman's reform policies generated resistance from establishment forces who were ideologically opposed to them or who stood to lose from them. There certainly was such resistance, as might be expected. What was striking about Abdurrahman's approach, was how little relationship there was between his coalition-building and coalitiondestroying efforts on the one hand and his reformist vision on the other. He made little effort to construct a broad coalition in favour of reform or to build a consistently reformist government. Ministers were sacked and appointed, with a few exceptions, not on the basis of how they would contribute to reform, but on the basis of whether they would advantage Abdurrahman in factional terms. ${ }^{1}$ Eventually, Abdurrahman Wahid himself made no efforts to preserve his own reforms, preferring to make concessions willy-nilly to his opponents in the attempt to shore up his own position. For instance, on the question of Aceh policy, he approved a return to military operations in the form of an April 2001 Presidential Instruction. Likewise, he willingly sacrificed Agus Wirahadikusumah and other reformist officers when it became necessary to strengthen his position in the military (Tentara Nasional Indonesia, TNI). Indeed, Abdurrahman eventually himself tried to bring the TNI back into the political arena, by ordering it to support a decree dissolving the legislature and allowing emergency rule.

In conclusion, during Abdurrahman's presidency what might have been a period of dramatic democratic transformation and consolidation was wasted. The reform momentum that still animated Indonesian politics at the end of the Habibie period was dissipated and diverted into endless petty disputes about Abdurrahman's behaviour, political representation and power-sharing. The public mood, previously strongly in favour of reform, became increasingly alienated from and indifferent to politics. Abdurrahman Wahid, lionised by many observers as the true champion of democratisation, is better viewed in retrospect as its antithesis.

\section{The Megawati Soekarnoputri presidency (July 2001-October 2004)}

In the mid-1990s, Megawati Soekarnoputri had become a potent symbol of resistance to Soeharto's rule, with minimal effort. She put forward no philosophically elaborate democratic program, but simply called for the regime

\footnotetext{
1 For example, Laksamana Sukardi, the PDI-P Minister for state enterprises, was widely viewed as both competent and relatively clean, and was replaced early on in Abdurrahman's term by the Nadhlatul Ulama politician, Rozy Munir. This move was generally seen as enabling the president and NU to more readily access the massive resources available to the ministry (Straits Times, 27 April 2000).
} 
to respect what it said were its own principles of rule-based government and constitutional propriety. In particular, she argued that the decision of the PDI to choose her as leader should be respected. This minimalist vision was both her strength and weakness. It allowed her to expose the regime's hypocrisy when Soeharto ousted her in 1996, but led to a strategic dead-end thereafter. As a result, Megawati and her followers played little role in the mobilisations that toppled Soeharto in 1998.

The important point, for current purposes, is that when Megawati came to power over the wreckage of the Abdurrahman presidency in July 2001, in conditions where a basically democratic institutional framework was already in place, it turned out that she was also ill-equipped to become either a visionary or even an effective reforming president. Her presidency, therefore, while not the fully fledged Indonesian Thermidor that some of her detractors suggested, did embody an ebbing of the reformasi tide.

Megawati's conservatism was obvious in many fields. Unlike Abdurrahman, who tried to appoint at least some noted reformers to key posts, Megawati curried favour with hawkish military men and former New Order stalwarts. She backed the reappointment of New Order era governors in the provinces, often against the wishes of the local branches of her own party. Especially disillusioning for her supporters was her patronage of Jakarta governor, Sutiyoso, the very man who as Jakarta military commander in July 1996 had organised a violent military assault on Megawati loyalists who were protesting against her ouster as PDI leader. As president, Megawati was also personally close to military officers, notably Army Chief of Staff General Ryamizard Ryacudu, who were very warlike on separatist conflicts and generally hostile to reform. She oversaw a dramatic return to authoritarian policies in Papua and Aceh, including (after a largely military-engineered collapse of another peace deal) the declaration of military emergency in Aceh in May 2003, under which all manner of gross abuses were committed.

The reform process did not entirely grind to a halt during Megawati's presidency, however. Some important legislative changes and institutional initiatives did occur, such as the establishment of a new anti-corruption body (Komisi Pemberantasan Korupsi, KPK), and the passage of the fourth amendment to the Constitution which provided, among other things, for the direct election of the president (Megawati first opposed this, but later acceded to it). In these cases, however, the initiative mostly came from forces within parliament and would likely have occurred whatever executive government was in power. Sympathetic commentators often say that Megawati succeeded in restoring stability and predictability to the government after the chaos of the Abdurrahman period, which is really another way of saying that she made few positive reforms. Others point to successes in restoring security, such as successful police action against 
the Bali bombers after October 2002 and peace deals in Maluku (late 2001) and Central Sulawesi (early 2002). In these cases, too, however, the chief initiative came from Megawati's subordinates. As president, Megawati was not simply conservative, she was also passive and aloof. She took little interest in policy development, provided little more than general statements of principle to guide her ministers, and allowed her trusted lieutenants to take the lead in setting the government agenda.

\section{Coalitions of opportunity}

How did the legacy of the New Order pattern of semi-opposition impact upon the generally disappointing reform outcomes of the Abdurrahman and Megawati presidencies? If space permitted, it might be possible to develop several different lines of argument. For example, Megawati's personal conservatism was itself arguably a product of years of political socialisation under the New Order. ${ }^{2}$ Her chosen vehicle for political action in those years, the PDI, was for much of the New Order an ineffective plaything of the government that lacked ideological independence. It might also be possible to emphasise the inculcation of a patrimonial political culture under Soeharto, whereby even office holders in the semi-oppositional political parties and mass organisations could expect material rewards for demonstrating loyalty to the government. When the leaders of such organisations later took political office it was unsurprising that many of them viewed ministries and other government bodies as ripe for exploitation. The resultant culture of corruption helped slow democratic reform.

The remainder of this chapter, however, will focus on just two New Order legacies. The first concerns the attitudes to political coalition building which resulted from the New Order years, the second to the personal styles of the leaders who rose to political prominence through the semi-oppositional route.

Both Abdurrahman Wahid and Megawati Soekarnoputri's governments were effectively grand coalitions of all the major political parties represented in parliament, plus the Armed Forces, with the addition of non-party professionals and bureaucrats. Abdurrahman's first cabinet of 35 members included four ministers from Golkar, as well as five from the TNI (six, if the military commander, who sat in cabinet meetings was included). Megawati's cabinet was based on a similar formula, and included several individuals who had earlier

2 Though as Angus McIntyre, 2005, pp.139-50 notes, a large part of Megawati's psychological formation also occurred prior to the New Order, and many of her public statements suggest a nostalgia for her father's Guided Democracy institutions and arrangements. (My thanks to Greg Fealy for this point.) 
served under Abdurrahman. ${ }^{3}$ So marked has been the power-sharing tendency that one observer (Slater 2004) has described Indonesia's national governments as being based on a 'party cartel' system.

It is possible to point to various origins of this tendency toward broad coalitions. One early antecedent is Sukarno's Nasakom (Nationalist-ReligiousCommunist) cabinets of the Guided Democracy period, as well as his even earlier discussions about the need to blend all the elements of Indonesian politics into a single form. More immediately, broad party coalitions were of course partly a response to the extremely fragmented nature of the political map after the 1999 elections. Any president who wanted to secure a workable majority in the parliament had to ensure that he or she had the support of several political parties. Yet the coalition building which took place was curiously unselective. In many transitional democracies, coalition-building choices are often dictated by parties' role in the former non-democratic regime. For example, in postcommunist countries in East and Central Europe, former communist parties were routinely excluded from coalition governments during at least the early phases of democratic transition. In Indonesia, by contrast, there was almost complete disregard for party origin, ideology or democratic potential. The aliran-based parties of former semi-opponents, which claimed to embody the new spirit of reformasi, shared power more or less equally with individuals and forces that had been the main supports of the Soeharto regime.

Other patterns would have been possible. An opportunity to create an antiNew Order coalition had arisen between the first post-Soeharto election of June 1999 and the People's Consultative Assembly (Majelis Permusyawaratan Rakyat, MPR) session of October 1999 when Abdurrahman was elected to the presidency. During this period, many critical intellectuals, student and NGO activists argued for a 'reformasicoalition' built around the major parties representing the biggest of the old semi-oppositional aliran. Megawati's PDI-P, Abdurrahman Wahid's PKB and Amien Rais's PAN together commanded 262 of the 550 seats in the DPR, and had a majority of 320 if the PPP was included; in the MPR the numbers were tighter, but the old semi-oppositional forces still had a theoretical majority. Despite considerable agitation in favour of such a coalition, including from the grassroots of these parties, Abdurrahman Wahid instead came to power by first securing the support of a 'central axis' (poros tengah) of Islamic parties and then by successfully wooing the military and the dominant Habibie wing of Golkar (Mietzner 2000). To secure this outcome, he made promises of cabinet seats and other important government posts, and also pledged to protect the corporate interests of the military and other key players (Mietzner 2004:191).

3 With a little more modification, notably the exclusion of Megawati's PDI-P, Susilo Bambang Yudhoyono's government since 2004 has also been based on the same essential formula. 
Abdurrahman's construction of a coalition of opportunity, with the sole aim of securing the presidency for himself, had a dramatic effect on the political dynamic in Indonesia. As I have argued elsewhere (Aspinall 2002), it blurred the line between Indonesia's authoritarian past and its democratic future. Most obviously, it did this by bringing individuals and political forces opposed to reform into the highest level of government, where they could sabotage reform from within. For example, key political posts including the Coordinating Ministry of Political and Security Affairs, and the Home Affairs Ministry, were reserved for military men, with the result that TNI retained the ability to dictate the pace of its own reform.

More generally, Abdurrahman's strategy greatly complicated and blurred the political map. Previously, forces in civil society such as student groups and NGOs had been able to push forward Indonesia's political transition because they believed they had a clear target: governments representing the 'status quo', first under Soeharto and then under Habibie. Such groups now found it hard to say whether the government represented reformist or ancien regime interests, and many of them became disoriented or split as they debated whether or in what way they should support the new president and his government (e.g. Kompas, 7 March 2001; 7 June 2001). To make matters even more complicated, Golkar under Habibie and Akbar Tanjung had done an effective job of presenting itself as a force favouring reform: it was Golkar's Slamet Effendy Yusuf and ex-Golkar leader Jacob Tobing who drove the main constitutional reforms through the MPR. Especially in the later phases of his presidency, Abdurrahman tried to appeal to the activist groups by depicting himself as a victim of Golkar and other reactionary forces. However, by then it was too late; many of them had lost faith in the president or become entirely disillusioned from the official politics.

Equally fundamentally, the major political parties were no longer aligned for or against the government per se (though they quickly developed positions on Abdurrahman himself). Now, each party was represented inside government and had little incentive to compete to present a more convincing reformist face to the public. Bereft of the disciplining effects of either being in opposition or fending off opposition, they instead became preoccupied with struggling for position and resources inside government. We do not know what would have happened had the government which came to power in October 1999 been based on a reformasicoalition, but it surely would have imparted a very different political dynamic to the following years.

For the purposes of the argument presented here, it is important to stress that the tendency toward building grand coalitions was itself a natural product of the previous regime's semi-oppositional culture. Under the New Order, individuals who aspired to lead the major parties and ormas were required to cultivate links with patrons and protectors within the regime. Even when 
Megawati Soekanoputri alienated Soeharto and his camp in the 1990s, she and her followers strove to cultivate links with sympathetic elements in the officer corps. She received invitations to speak at officer training courses, and a congenial officer from the state intelligence agency (Badan Koordinasi Intelijen Negara, BAKIN) accompanied her wherever she went on party business and was popular with her retinue (field notes, June 1995). In the late 1980s and early 1990s, Abdurrahman Wahid tried to secure political advantage and advance the cause of reform by identifying himself with military officers who were becoming disillusioned with the president; he was personally close to the senior general L. B. (Benny) Moerdani. In 1996-97 he had hastily realigned Nahdlatul Ulama toward president Soeharto and his family. To continue the contrast with postcommunist transitions: individuals like Vaclav Havel or Lech Walesa viewed the former ruling parties and their leaders across a gulf of hostility; in Indonesia, the new democratic leaders were long used to seeing their equivalents as potential allies. They simply continued this habit when they came to power.

\section{Politics of personality}

A second legacy of the New Order semi-oppositional background can be found in the personal styles of the first two post-New Order leaders themselves. Abdurrahman and Megawati had in some ways very different, almost diametrically opposed, personal styles. Whereas Abdurrahman was hyperenergetic, reckless and earthy in his approach to politics, Megawati was passive, cautious and aloof. Yet underpinning these great differences was a similar inflexibility of political style. Despite the many compromises they had made as semi-opponents during the Soeharto years, once they became president, both seemed to share an utter conviction of the rightness of their own course and an unwillingness to compromise, even on trivial matters, when their personal prestige was affected. It is surely more than a coincidence that Indonesia's first two post-New Order presidents shared similar flaws as political leaders.

Their personalities contributed to their political failings, and to the problems of Indonesia's political transition. Abdurrahman's contempt for the coalition partners who had delivered him the presidency has already been remarked upon. His recklessness, indeed, the delight he apparently took in antagonising both friends and foes led to the destruction of his government and succeeded in making himself, rather than political reform, the major issue in post-Habibie politics. Megawati, by contrast, embodied a kind of arch passivity which was similarly destructive. Abdurrahman's opportunism has already been noted as one key cause of the stillbirth of the 'reformasicoalition' dream of 1999; Megawati was equally responsible. Between June and October 1999, Megawati made almost no attempt to court potential allies or reassure them of her 
intentions. Instead, she alienated other party leaders by acting as if she believed the presidency was hers by right, merely because her party had won a plurality of the vote. As president, she seemed equally unconcerned about the views of even her most loyal supporters, as her willingness to ride roughshod over them in gubernatorial races demonstrated. Criticisms of her by members of the public brought outbursts of petulance, such as when she angrily condemned student protestors who burned her image or effigy during demonstrations (McIntyre 2005:248). Eventually, even her close supporters admitted during the 2004 presidential elections that her unsympathetic public image was a liability, and they tried to soften it. In summary, Abdurrahman and Megawati's personalities played a major role in crippling their presidencies, forestalling reforming coalitions and thus in damaging the reform process itself.

Abdurrahman's and Megawati's personalities were produced by the distinct political cultures of their respective milieux, and by the special places both occupied therein. The two were similar, however, in how they came to prominence and in how they were viewed by their followers. Both became leaders not largely because of what they said or did, but because of who they were. Megawati's father, the republic's charismatic founding president, had been the focus of cult-like veneration both before and after his death. Megawati was wholly unremarkable as a parliamentarian before she was elevated to head the PDI on a wave of Sukarnoist nostalgia in 1993. (Aspinall 2005:145-76; McIntyre 2005:155-75; Brooks 1996). During fieldwork in the mid-1990s, I attended several PDI public functions where party supporters greeted Megawati's banal utterances with evident rapture. One can only imagine the aggrandising effect such a reception must have had on her sense of herself; certainly Megawati developed an obvious sense of entitlement by the late Soeharto years.

Abdurrahman Wahid, as grandson of the founder of Nadhlatul Ulama and son of K. H. Abdul Wahid Hasjim, its revered chairperson and Minister of Religion in the 1950s, had similarly aristocratic credentials within the traditionalist Islamic aliran. Unlike Megawati, he had shown signs of real intellectual ability when young, and was catapulted at a relatively early age to head NU in 1984. His great oratorical and intellectual capacities marked him out from other members of his extended family, who failed to capture such high office in NU. Unlike Megawati, he was the standout figure among his cohort and the lineage alone was not enough to make him NU leader. ${ }^{4}$ Even so, his family background did contribute to the mystique which surrounded him. By at least the early 1990s many of Abdurrahman's followers venerated him as a wali or saint, strove to kiss his hand at public events, and believed that his more peculiar actions and utterances were simply beyond the ken of ordinary people (Fealy 2001). Being surrounded for many years by people - and not merely by a thin layer

4 My thanks to Greg Fealy for this point. 
of sycophants, but a massive social constituency - who believed that whatever he did was correct even if they could not understand it, must largely explain Abdurrahman's imperviousness to criticism and the recklessness of his political behaviour while in office (although as McIntyre (2005:252) points out, the effects that two strokes had on his cognitive powers likely also played a part).

It is not only in Indonesia, of course, where populist leaders come to power because of their dynastic credentials or because they are viewed by followers as mystically embodying popular aspirations. However, to return to the chief argument of this chapter, the New Order political dynamic helped to push such individuals forward, because it blocked pathways for different types of leaders. Under the New Order, it was not possible to become a prominent critic of the regime by serving a lengthy political apprenticeship in a modern political organisation, convincing first one's own followers and then a broader public of the rightness of one's political vision and the acuity of one's political skills. The New Order system was designed precisely to prevent such alternative leaders from emerging. Instead, Megawati and Abdurrahman became leaders because they were seen by their followers as embodying their own diffuse sentiments and aspirations. They were adored not for the actions or utterances, but for what they symbolised. The end result was that Indonesia's political transition was steered by individuals who, when they came to power, had already accumulated the hubris, inflexibility and arrogance that one often only sees in ageing political leaders who have long enjoyed the fruits of office.

\section{Conclusion: was the New Order really to blame?}

The argument so far advanced in this chapter has been relatively straightforward: Indonesia's democratic transition has been influenced by the legacy of the preceding authoritarian regime. It has been marked not merely in the obvious ways of there being remnants of New Order power (the army, oligarchy, bureaucracy, etc) which obstruct reform, or patterns of New Order political behaviour (patrimonialism, repression, corruption, etc) which erode it. The trace of the New Order was also visible at the heart of the first postauthoritarian governments. The way that the New Order regime dealt with potential opposition, by combining repression and selective tolerance, left a lasting impact on Indonesia's democratic leaders. Those forces and leaders who were able to seize the political initiative when the old regime collapsed brought with them the political habits that had been inculcated in them by the experience of semi-opposition. 
In conclusion, however, it might also be apposite to question the argument so far developed in this chapter. As noted at the outset, there is a tendency in much of the scholarship of the post-New Order era to ascribe whatever observers feel to be negative features of the new political system to the 'legacy of Soeharto' (or some such phrase). The argument presented thus far in this chapter is a version of this approach, albeit one which focuses specifically on the effects of the semioppositional pattern of politics of the New Order years.

Obviously, we cannot write the New Order period out of Indonesian history. The political system which has developed in Indonesia since 1998 has a direct connection to the preceding 33 years. But it is also striking that many of the phenomena we see in post-Soeharto Indonesia also have much deeper historical roots, and are similar to phenomena which occurred during Indonesia's earlier period of democratic rule in the 1950s. For example, when considering the record of Abdurrahman Wahid's government, including the extreme pragmatism Abdurrahman exhibited when forging political alliances, and the willingness of members of his retinue to see ministries and other state institutions as sources of patronage, there are striking parallels with the political behaviour of Nahdlatul Ulama in the 1950s and early 1960s. In that period, NU became known for the extreme flexibility, bordering on opportunism, of its political alliances, and for its corruption, with the Ministry of Religion becoming a virtual NU fiefdom (Fealy 1998). Likewise, it is also possible to detect many similarities between Megawati Soekarnoputri's behaviour when in power and that of the right-wing of the Sukarnoist Indonesian National Party (Partai Nasional Indonesia, PNI) in the 1950s and 1960s.

In short, in some crucial respects, the politics of post-Soeharto Indonesia are strikingly reminiscent of the earlier democratic period in the 1950s, especially in the tendency toward formation of broad and opportunistic coalitions, and the ubiquity of the patrimonial style. Similarities with Guided Democracy in the 1960s - especially the tendency toward unity governments - are also obvious. These observations point toward other research agendas, which would involve placing post-Soeharto Indonesia in longer historical perspective. They also perhaps suggest that we need to re-think the New Order period itself in more fundamental ways.

In the past, it was customary to view Indonesian politics as being marked by a sharp break in 1965-66 when the New Order regime was established. Before that time, the major schism in Indonesian politics was between the left, centred on the communist party (Partai Komunis Indonesia, PKI) on the one hand, and the other major political forces, including the parties and the military, on the other. After the destruction of the PKI and the murder of its adherents in 
1965-66, so the conventional wisdom holds, the main axis of politics shifted. A government dominated by the military and bureaucracy now subjected all preexisting civilian forces to its dominance.

But given the ease with which the semi-opponents of the New Order years transformed themselves into coalition partners of their erstwhile rulers after 1999, it is perhaps more appropriate to view the New Order in retrospect as a project of a broader spectrum of the Indonesian elite. Modernist and traditionalist Muslims and Sukarnoist nationalists were incorporated into that regime in subordinate positions, but they had a stake in it nonetheless. They recognised its legality, accepted its rules, agreed with much of its ideology and valued the order and economic benefits it produced. As events since 1999 have shown us, they were certainly not so alienated from it that they rejected all of its legacy once they were able to take power for themselves. 